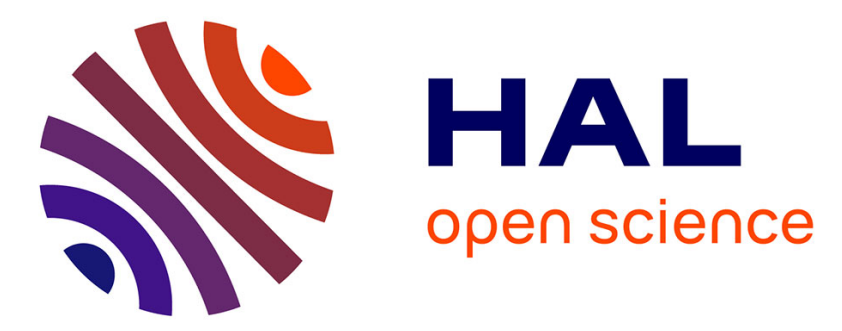

\title{
In seroconverted rheumatoid arthritis patients a multi-reactive anti-herpes IgM profile is associated with disease activity
}

Regina Larionova, Marina Arleevskaya, Olga Kravtsova, Shamil Validov, Yves

Renaudineau

\section{- To cite this version:}

Regina Larionova, Marina Arleevskaya, Olga Kravtsova, Shamil Validov, Yves Renaudineau. In seroconverted rheumatoid arthritis patients a multi-reactive anti-herpes IgM profile is associated with disease activity. Clinical Immunology, 2019, 200, pp.19-23. 10.1016/j.clim.2019.01.004 . hal-01995998

\section{HAL Id: hal-01995998 \\ https://hal.science/hal-01995998}

Submitted on 21 Oct 2021

HAL is a multi-disciplinary open access archive for the deposit and dissemination of scientific research documents, whether they are published or not. The documents may come from teaching and research institutions in France or abroad, or from public or private research centers.
L'archive ouverte pluridisciplinaire HAL, est destinée au dépôt et à la diffusion de documents scientifiques de niveau recherche, publiés ou non, émanant des établissements d'enseignement et de recherche français ou étrangers, des laboratoires publics ou privés.

\section{(c) (1) $\$$}

Distributed under a Creative Commons Attribution - NonCommerciall 4.0 International 


\title{
In seroconverted rheumatoid arthritis patients a multi- reactive anti-herpes IgM profile is associated with disease activity
}

\author{
Short title: herpes infections among RA patients
Regina V Larionova ${ }^{1^{*}}$, Marina I Arleevskaya ${ }^{{ }^{*}}$, Olga A Kravtsova ${ }^{2}$, Shamil Validov ${ }^{3}$, Yves Renaudineau 1,4

\author{
${ }^{1}$ Central Research Laboratory, Kazan Federal University, Kazan, Russia \\ ${ }^{2}$ Department of Biochemistry and Biotechnology, Kazan Federal University, Kazan, \\ Russia \\ ${ }^{3}$ Laboratory of structural biology, Institute of fundamental medicine and biology, Kazan \\ Federal University, Kazan, Russia \\ ${ }^{4}$ Laboratory of Immunology and Immunotherapy, INSERM U1227, Hôpital Morvan, \\ Centre Hospitalier Regional Universitaire (CHU) de Brest, Brest, France
}

*Have contributed equally to this work

Email: Larionova RV : reginalarionova1993@mail.ru; Arleevskaya MI: marleev@mail.ru; Kravtova OA : okravz@yandex.ru; Validov S : SZValidov@kpfu.ru; Renaudineau Y : yves.renaudineau@univ-brest.fr

Corresponding author: Yves Renaudineau, Laboratory of Immunology and Immunotherapy, Brest University Medical School Hospital, BP 824, F-29609, Brest, France. Phone: 33-298-22-33-84; Fax: 33-298-22-38-47; yves.renaudineau @ univ-brest. 


\begin{abstract}
Conflicting results have been reported regarding human herpes virus (HHV) reactivation in patients with rheumatoid arthritis (RA). To explore this link, 74 RA patients were selected and compared to 42 first degree relatives (FDR) from probands with RA and 25 healthy controls from the Tatarstan women cohort. The serological analysis was done by testing anti-HSV/CMV/EBV IgM, IgG, plus the IgG avidity index, and completed by evaluating HSV/CMV/EBV DNA by PCR. Results from these analyses reveal: (i) a long lasting infection of HHV in RA, FDR and healthy controls (IgG seroconversion >97\%); (ii) an elevated IgM anti-HHV response in seroconverted RA patients which is related to HSV1/2 reactivation (HSV1/2 PCR+); and (iii) a multi-reactive $\operatorname{IgM} \mathrm{HHV}$ burden profile associated with disease activity (DAS28). In conclusion, HSV1/2 reactivation in seroconverted RA patients is associated with an abnormal anti-HHV immune response, which was reflected in IgM HHV burden, and in activity disease profile.
\end{abstract}

Key words: rheumatoid arthritis, HSV, CMV, EBV, reactivation, disease activity

\title{
Highlights:
}

- The link between herpes viruses and Rheumatoid Arthritis (RA) is unknown.

- HSV1/2 reactivation promotes an $\operatorname{IgM}$ herpes virus multi-reactivity profile in RA.

- IgM herpes virus multi-reactivity profile is associated with disease activity in RA.

- A normal immune response is reported in first degree relatives and controls. 


\section{Introduction}

Characterized by inflammation in the synovium and joint damage, rheumatoid arthritis (RA) is a chronic systemic autoimmune disorder. Although the pathogenesis of RA remains to be determined, a combination of environmental, epigenetic and genetic factors influences disease onset [1,2]. Among infectious agents, the human herpes viridae (HHV) family is suspected of being associated with RA including herpes simplex viruses (HSV) 1 and 2, varicella-zoster virus (VZV), Epstein-Barr virus (EBV), and human cytomegalovirus (CMV) [3]. Arguments supporting this statement are related to the observations that RA patients have more reports of HHVs infection or reactivation, an increased prevalence of HHVs antibodies (Ab) in their serum, and a higher load of HHV DNA in their peripheral blood and synovial fluid [4]. However, the link between RA and HHVs remains to be established since several authors have failed to confirm such associations [5-7]. In addition patients with RA are also known to be at greater risk of infectious morbidity and mortality, including with HHVs, due to disease-related immune deficiencies that predominate in the early stage of the disease and later due to the use of immunosuppressive medications [8-11].

Most primary infections with HHVs are asymptomatic, and occur during the first two decades of life explaining why up to $90 \%$ of the adult world population presents a $\operatorname{IgG}$ seroconversion [12]. Classically in primary HHVs infections, specific IgM Abs appear within 4-7 days after infection, reaching a peak at 2-4 weeks, and declining thereafter. However, IgM detection is not exclusive for a recent primary infection since IgM reactivity could reflect viral reactivation or recurrent infections as frequently observed with this viral family. To circumvent this problem, the $\mathrm{IgG}$ avidity index assay was developed. Indeed, and in the case of IgM positivity, IgG negativity or IgG positivity with a low avidity (LA) index indicates a recent infection; while an IgG high avidity (HA) index highlights a past or reactivated/recurrent infection as a result of the stimulation of memory B cells. Moreover, DNA virus detection by PCR coupled with clinical information may help to establish a primary infection $(\mathrm{IgM}+/-$, IgG-/low avidity and PCR+) from an active reactivation or recurrence. 
In this study, our aim was to identify, during RA follow-up, three herpes viruses (HSV1/2, CMV, and EBV) using a serological approach by testing specific IgM, IgG, plus an IgG avidity index; a molecular approach by researching specific DNA; and a clinical approach to report HSV events in the previous year. To this end, a crosssectional study was conducted in 74 RA patients and compared with 42 first degree relatives (FDR) from probands with RA and 25 healthy controls (HC) from the longitudinal cohort of Tatarstan women. Hence in this three arm cohort of women, we have investigated the associations of HSV1/2, CMV, and EBV reactivation in relation to the RA disease stage evolution, inflammation ( $\mathrm{C}$ reactive protein [CRP]) and the erythrocyte sedimentation rate [ESR]), the disease activity score in 28 joints (DAS28), the response to a health assessment questionnaire (HAQ), the disease-modifying antirheumatic drugs (DMARDs) administered, plus the rheumatoid factor (RF) and anticitrullinated peptide antibody (ACPA) positivity. 


\section{Material and methods}

\subsection{Patients}

A cross-sectional study was made by selecting 74 RA patients, 42 FDR from probands with RA, and $25 \mathrm{HC}$ from the triple arm Tatarstan cohort study of women conducted between 1997 and 2018 at the Kazan State Medical Academy [13]. In this cohort, allergic diseases with detection of allergen-specific $\mathrm{IgE}$, and positivity for the human immunodeficiency virus (HIV) in the history are considered as exclusionary criteria. HC included subjects without any signs of chronic disease, and no RA among close relatives. RA diagnosis was established according to the 2010 ACR/EULAR classification criteria [14], and for patients diagnosed before 2010 they were reevaluated relative to these criteria since they were initially diagnosed using a consensus opinion from three experienced rheumatologists. The patients were asked to mark on the VAS (Visual analogue scale) of 0-100 mm scale according to their global assessment of disease activity, and we assessed the functional impact of the disease by the HAQ and disease activity by DAS28 $[15,16]$. CRP values, as determined by the nephelometric method, were used in the calculation of DAS28-CRP [17]. Obtained from the outpatient records, $\mathrm{RF}$ and anti-CCP2 auto-antibody $(\mathrm{Ab})$ were categorized into three groups based on the RF or anti-CCP2 Ab cut-off levels: negative, intermediate (1-3 times the reference cut-off level), and high ( 3 times greater than the reference cut-off level) [14]. In order to evaluate symptomatic and asymptomatic HSV, individuals were asked at the time of sample collection about the number of HSV infectious episodes, mainly oral or genital blisters, in the previous year as reported $[13,18]$. Zoster events were not reported. The study was approved by the Ethics Committee of the Kazan State Medical Academy, Kazan, Russia (Permit nr 1/2002). Consent was received from all the individuals involved in the study, including consent to participate in the study and consent to allow publication of the results. Samples were collected in the absence of any clinical signs of infection including herpes infection, frozen and remained at $-80^{\circ} \mathrm{C}$ until assayed. 


\subsection{ELISA and real time PCR}

The "Vector" enzyme immunoassay kits for detection of the $\operatorname{IgM}, \operatorname{IgG}$, and $\operatorname{IgG}$ avidity index values (>60\% indicating HA) against HSV1-2, CMV and EBV were used and results obtained according to the manufacturer's specifications (Vector Best, Novosibirsk, Russia). The "Real Best" DNA -HSV1/2, -CMV and -EBV kits from Vector Best and containing reagents for end point quantitative real time PCR were used to detect HSV1/2 with primers complementary to the envelop glycoprotein D gene, CMV with primers located between RNA 2.7 and RL5A genes on an intergenic region, and EBV with primers complementary to the latent membrane protein $2 \mathrm{~A}$ gene. Total DNA was extracted from peripheral blood by the phenol-chloroform method [19]. In addition, for HSV1/2, DNA was extracted from the buccal epithelium and cervical secretions when available. The DNA concentration was determined by spectrometry, and extracted DNA samples were stored at $-80^{\circ} \mathrm{C}$ prior to use. Each PCR run included one negative control to exclude the possibility of contamination during PCR with the Bio-Rad thermocycler and each sample was analyzed in duplicate.

\subsection{Statistics}

Continuous data are described as the mean \pm standard error of the mean (SEM) and are analyzed by using a non-parametric U-test (Mann-Whitney), while the Fisher's exact test was used for categorical data. The results were corrected for multiple testing using the false discovery rate online calculator based on the Benjamini-Hochberg method and $\mathrm{p}$ values under 0.05 were considered significant (https://www.sdmproject.com/utilities/?show=FDR). Statistical analyses and heat maps were performed using GraphPad Prism 7.0a (La Jolla, CA). 


\section{Results}

\subsection{HSV1/2, EBV and CMV serological profiles in RA}

For this study, patients with RA ( $\mathrm{n}=74)$ were selected from the Tatarstan women's longitudinal triple arm cohort and compared to FDR individuals $(n=42)$ and HC $(n=25)$. Next, and in order to appreciate the anti-HSV1/2, anti-EBV and anti-CMV immune response during RA, the specific IgG Ab, IgG avidity index, and specific IgM $\mathrm{Ab}$ were tested (Figure 1). Almost all RA patients, FDR and healthy controls had been infected for a long time by HSV1/2 (97.3\%), EBV (98.6\%) and CMV (100\%) based on the high IgG Ab levels reported for all three of these viruses and the results of the IgG avidity index. Regarding IgM levels, they were higher in RA than in the control groups when considering $\operatorname{IgM}$ anti-HSV1/2 $\mathrm{Ab}(0.252 \pm 0.037$ in RA versus $0.127 \pm 0.031$ in FDR and $0.103 \pm 0.019$ in $\mathrm{HC}, \mathrm{p}=0.0003$ and $\mathrm{p}=0.0005$ respectively, data not shown). Moreover, a reactivated/recurrent infection phenotype coupling IgM positivity with $\mathrm{IgG}+/ \mathrm{HA}+$ was significant in RA patients for $\mathrm{HSV}$ ( $\mathrm{p}=0.021$ ), EBV $(\mathrm{p}=0.025)$ and $\mathrm{CMV}(\mathrm{p}=0.004)$ (Figure 1A-C).

\subsection{Multi-reactive IgM antibodies}

Showing that bi/tri-reactivation events concerned 10/14 (71.4\%) anti-HSV1/2 IgM, $7 / 19$ (36.8\%) anti-CMV IgM, and 6/11 (54.5\%) anti-EBV IgM in RA patients, this raised the question of an IgM multi-reactivity profile between HHV family members that may occur during HHV reactivation/recurrence (Figure 1D). To test such a hypothesis IgM anti-HHV levels were compared according to the: (i) virus detection (PCR+) in the blood (HSV1/2, EBV and CMV) and/or in the buccal epithelium or cervical secretions for HSV1/2; (ii) report of a HSV event, mainly blisters, in the previous year to distinguish symptomatic from asymptomatic HSV individuals; and (iii) clinical status as obtained in RA or in the control group (FDR and HC).

First, with regards to the HSV1/2 PCR positive group (RA: 10/47 [21.3\%]; FDR and HC: $11 / 45$ [24.4\%]), elevated levels of anti-HSV IgM Ab (p=0.05), anti-EBV IgM Ab $(\mathrm{p}=0.003)$, and anti-CMV $\operatorname{IgM~Ab}(\mathrm{p}=0.05)$ were observed in the RA group with a HSV 1/2 PCR positive test. Since such associations were not observed in the control 
groups, this supports the possibility that HSV reactivation not only promotes anti-HSV IgM Abs but also anti-EBV and anti-CMV IgM Abs in RA patients. Second and when considering symptomatic versus asymptomatic RA patients to HSV in the previous year, the hypothesis of a recurrence of HSV was excluded by the absence of difference when regarding anti-HSV IgM antibody levels and to the fact that HSV PCR+ were found in both the symptomatic (3/17 [17.6\%]) and asymptomatic (7/30 [23.3\%]) subgroups. Third, when EBV PCR positivity was used to dichotomize individuals (RA: $n=5 / 40$ [12.5\%]; FDR and HC: n=4/37 [10.8\%]) no differences were reported regarding IgM HHV levels. Fourth, with only one individual (RA patient) testing positive for CMV by PCR, the association with IgM HHVs was not explored further. Altogether, this supports the possibility that the abnormal IgM poly-reactive HHV immune response observed in RA is related to a HSV1/2 reactivation process.

\subsection{Multi-reactive IgM antibodies and disease activity}

Finally, and considering that an anti-HHV multi-reactive profile has been associated with chronic inflammation [20], we next subdivided the RA patients into two groups: those multi-reactive for anti-HHV $\operatorname{IgM}$ ( $\geq 2$ positive tests, burden infection) and those mono-reactive or negative for anti-HHV IgM (Table 1). The anti-HHV multi-reactive profile was associated with disease activity (DAS28-CRP, $\mathrm{p}=0.024$ ). In contrast, no differences were reported when considering VAS, HAQ, ESR, CRP, RF/CCP positivity, DMARDs intake, and the immunomodulating agent used.

\section{Discussion}

In this study we have investigated a possible association between RA and HHV primary infection, reactivation, and recurrence (i.e. reinfection). To strengthen the demonstration of this association, several factors were considered: the use of a different technology coupled with clinical data to report an active HHV reactivation, the use of FDR and HC as control populations, and the time point of the analysis in the follow-up of the disease.

Results from the present study support a role for HSV reactivation in driving an abnormal anti-HHV IgM immune response. This is, first, based on the observation that 
more than $97 \%$ of the studied population was positive for HSV IgG and presented an avidity index $>60 \%$ for IgG $(\mathrm{HA}+)$ which excludes a primary infection [21]. Second, and within RA patients with a long established HSV infection, the serological screening for IgM coupled with PCR results further supported an active HSV1/2 reactivation in up to $19 \%$ of the tested patients. As differences concern the $\operatorname{IgM}$ response, not the PCR response, primarily a defective immune system in patients with RA is suspected, and this hypothesis needs to be further explored. Next a serological HSV recurrence during RA was excluded as we failed to confirm an association with IgM anti-HSV levels when considering symptomatic and asymptomatic HSV reports in the previous year. Third, multi-reactivity for anti-HSV IgM Ab with anti-CMV IgM and anti-EBV $\operatorname{IgM}$ was suspected based on the indirect observation that HSV1/2 PCR+ RA patients have elevated levels of IgM anti-HHVs compare to HSV1/2 PCRRA patients. Altogether, HSV reactivation assessment is challenging and necessitates relying on a large panel of serological and molecular methods [12]. This is not surprising as HHV family members establish latent infections with reactivation possible, especially when the cellular immune system is compromised as reported in RA [9].

Due to defective control by the cellular immune system, persistent pathogens and multiple viral reactivations including HSV 1/2, CMV and EBV can act as a source of inflammation through proinflammatory cytokine production (e.g. IL-6) that could influence the immune system [22,23]. Such an association between the infectious burden and chronic inflammation (high CRP levels, elevated fibrinogen) has been associated with an increased cardiovascular risk, diabetes type 2, Alzheimer's disease and symptoms of depression in older adults [20,24]. In RA, a role for HHVs in the development of RA remains inconclusive and with occasional associations reported for $\mathrm{HSV} 1 / 2, \mathrm{EBV}$, but not for CMV [4,7]. As a consequence, and instead of a causative agent, a serological infectious burden, including HHV members, is attractive and in agreement with the geographical overlaps highlighted in HC between infectious serological markers and autoantibodies [25]. Others have established a link between the $\mathrm{IgG}$ immune response to EBV and parvovirus B19 IgG with anti-CCP positivity has been established in RA [21,26]. Our study supports a link between the infectious 
burden and disease activity. Further investigations are now required to address the mechanisms behind these findings and, in particular, the implication of the immune system in this process.

Immune responses against HSV are complex with a tight interplay between innate and adaptive immune responses. These responses involve the toll like receptors (TLR) and TLR2/4/9 engagement by HSV results in activation of nuclear factor kappa B (NF$\kappa \mathrm{B})$, secretion of proinflammatory cytokines and the development of autoreactive lymphocytes [27-29]. As a consequence, blocking the TLR9-mediated proinflammatory response with drugs such as hydroxychloroquine or Janus kinaseinhibitors acting upstream of TLR9 control the inflammatory response but with the risk of developing herpes zoster in RA [30-32], which supports a dysregulated TLR9 pathway in RA and with a possible amplification loop mediated by HSV. Metaanalysis and genome-wide association studies have linked several TLR polymorphisms and the gene encoding phospholipase D4 (PLD4) that causes a breakdown of the TLR9 signalling to RA [33,34]. Associations between functional TLR pathway variants and RA disease activity (DAS28) have been established for MyD88-rs7744 and TLR4-rs1927911 [35,36].

Biologic response modifiers including the use of anti-tumor necrosis factor (TNF) blockers were initially associated with an increased susceptibility to viral infection/reactivation compared with patients on conventional DMARDs [37,38]. This bias could be ruled out from our study since most of the selected patients were treated with conventional DMARDs except for two patients on rituximab, a non-anti-TNF biologic DMARD. In a recent study [39], we have further reported that HSV events were increased at the preclinical stage of RA and associated with a higher occurrence reported of morning stiffness and arthralgia when exploring untreated FDR developing RA in the Tatarstan cohort. As a consequence, this supports the possibility that HSV reactivation observed during RA is not related to biologic DMARDs intake but to the disease and is associated with disease activity. 
This study has potential limitations. First, it is a single center study and all participants were women. The relatively small number of individuals tested is another limitation in terms of statistical power. Regarding strengths, the current work is one of the first studies exploring a large panel of serological and molecular assays together with clinical information in RA. The recruitment of FDR via patients with RA is another strength [40]. Other strengths are related to the fact that such a study has investigated not only HHVs infection/reactivation but also recorded HSV events.

In conclusion, the immune response to HSV reactivation during RA disease can be considered as a relevant scenario associated with disease activity. More research is needed in order to better understand the cross-talk between RA-associated immune dysregulation, HSV reactivation and disease activity.

Conflict of interest: none

Funding: This study was supported by research funding from the "Russian Science Foundation” (№ 17-15-01099). Datasets from the current study are available from the corresponding author on reasonable request.

Acknowledgements: We are thankful to Dr. Wesley H. Brooks (University of South Florida, USA) for editorial assistance, and to Simone Forest and Genevieve Michel for secretarial assistance.. 


\section{Figures and legends}

Figure 1. Multi-reactive IgM anti-human herpes virus (HHV) antibodies in rheumatoid arthritis (RA) are related to an active reactivation of herpes simplex virus 1/2 (HSV1/2). A-C: Heat map showing in RA, first degree relatives (FDR) from probands with RA, and healthy controls (Cont) the serological profile for HSV1/2, Epstein-Barr virus (EBV), and human cytomegalovirus (CMV). D: Inter-relations between IgM anti-HSV1/2, IgM anti-CMV and IgM anti-EBV in 74 patients with RA. E- Influence of HSV1/2 PCR positivity (left), of an HSV event reported in the previous year (symptomatic [A] versus asymptomatic [AS], middle), and EBV PCR positivity (right) in patients with RA. F- In first degree relatives (FDR) of probands with RA and healthy controls ( $\mathrm{n}=42$ and 25 , respectively). Statistics are indicated when $p<0.05$ after correction using the BenjaminiHochberg method for multiple testing comparisons. 
Table 1. The IgM multi-reactive anti-human herpes virus (HHV) profile is associated with disease activity in rheumatoid arthritis.

\begin{tabular}{ccccc}
\hline & $\begin{array}{c}\text { HHV IgM } \\
\text { multi-reactive }\end{array}$ & $\begin{array}{c}\text { HHV IgM } \\
\text { no }\end{array}$ & Statistics & $\begin{array}{c}\text { Multiple analysis } \\
\text { correction }\end{array}$ \\
\hline age in years & $47.5 \pm 2.4$ & $51 \pm 1.6$ & 0.398 & 0.584 \\
DAS28-CRP & $5.2 \pm 0.3$ & $4.0 \pm 0.3$ & $\mathbf{0 . 0 0 2}$ & $\mathbf{0 . 0 2 4}$ \\
VAS (0-100mm) & $57 \pm 9$ & $37 \pm 4$ & 0.037 & 0.222 \\
HAQ & $2.6 \pm 0.6$ & $1.7 \pm 0.3$ & 0.139 & 0.300 \\
ESR (mm/1st $\mathrm{h})$ & $28 \pm 4$ & $30 \pm 3$ & 0.642 & 0.701 \\
CRP (mg/L) & $27 \pm 6$ & $17 \pm 2.5$ & 0.132 & 0.300 \\
$\begin{array}{c}\text { RF/CCP2 } \\
\text { neg / low / high }\end{array}$ & $0 / 0 / 9$ & $9 / 11 / 34$ & 0.113 & 0.300 \\
DMARDs $(\%)$ & $11 / 13(84.6 \%)$ & $47 / 53(88.7 \%)$ & 0.150 & 0.300 \\
methotrexate & 8 & 28 & 0.224 & 0.384 \\
sulfasalazine & 1 & 3 & 0.750 & 0.750 \\
$\begin{array}{c}\text { leflunomide } \\
\text { rituximab }\end{array}$ & 2 & 14 & 0.438 & 0.584 \\
\hline
\end{tabular}

Abbreviations: DAS28: disease activity score in 28 joints; VAS: visual analogue scale; HAQ: health assessment questionnaire; ESR: erythrocyte sedimentation rate; CRP: C-reactive protein; RF: rheumatoid factor; CCP: anti-cyclic citrullinated protein antibodies; DMARDs: disease-modifying anti-rheumatic drugs. 


\section{References}

[1] J.S. Smolen, D. Aletaha, A. Barton, G.R. Burmester, P. Emery, G.S. Firestein, A. Kavanaugh, I.B. McInnes, D.H. Solomon, V. Strand, K. Yamamoto, Rheumatoid arthritis, Nat Rev Dis Primers 4 (2018) 18001.

[2] W.H. Brooks, C. Le Dantec, J.O. Pers, P. Youinou, Y. Renaudineau, Epigenetics and autoimmunity, J. Autoimmun. 34 (2010) J207-219.

[3] M.I. Arleevskaya, O.A. Kravtsova, J. Lemerle, Y. Renaudineau, A.P. Tsibulkin, How Rheumatoid Arthritis Can Result from Provocation of the Immune System by Microorganisms and Viruses, Front Microbiol 7 (2016) 1296.

[4] R. Burgos, G. Ordonez, J. Vazquez-Mellado, B. Pineda, J. Sotelo, Occasional presence of herpes viruses in synovial fluid and blood from patients with rheumatoid arthritis and axial spondyloarthritis, Clin. Rheumatol. 34 (2015) 1681-1686.

[5] R.J. Ball, A. Avenell, L. Aucott, P. Hanlon, M.A. Vickers, Systematic review and meta-analysis of the sero-epidemiological association between Epstein-Barr virus and rheumatoid arthritis, Arthritis Res. Ther. 17 (2015) 274.

[6] L. Zhang, S. Nikkari, M. Skurnik, T. Ziegler, R. Luukkainen, T. Mottonen, P. Toivanen, Detection of herpesviruses by polymerase chain reaction in lymphocytes from patients with rheumatoid arthritis, Arthritis Rheum. 36 (1993) 1080-1086.

[7] F.M. Kudaeva, M.R. Speechley, J.E. Pope, A systematic review of viral exposures as a risk for rheumatoid arthritis, Semin Arthritis Rheum (2018).

[8] J. Avouac, F. Amrouche, C. Meune, G. Rey, A. Kahan, Y. Allanore, Mortality profile of patients with rheumatoid arthritis in France and its change in 10 years, Semin Arthritis Rheum 46 (2017) 537-543.

[9] C.M. Weyand, J.J. Goronzy, Immunometabolism in early and late stages of rheumatoid arthritis, Nat. Rev. Rheumatol. 13 (2017) 291-301.

[10] R.J. Desai, K.J. Thaler, P. Mahlknecht, G. Gartlehner, M.S. McDonagh, B. Mesgarpour, A. Mazinanian, A. Glechner, C. Gopalakrishnan, R.A. Hansen, Comparative Risk of Harm Associated With the Use of Targeted Immunomodulators: A Systematic Review, Arthritis Care Res (Hoboken) 68 (2016) 1078-1088.

[11] O.M. Castaneda, F.J. Romero, A. Salinas, G. Citera, E. Mysler, O. Rillo, S.C. Radominski, M.H. Cardiel, J.J. Jaller, C. Alvarez-Moreno, D. Ponce de Leon, G. Castelli, E.G. Garcia, K. Kwok, R. Rojo, Safety of Tofacitinib in the Treatment of Rheumatoid Arthritis in Latin America Compared With the Rest of the World Population, J. Clin. Rheumatol. 23 (2017) 193-199.

[12] E. Mendelson, Y. Aboudy, Z. Smetana, M. Tepperberg, Z. Grossman, Laboratory assessment and diagnosis of congenital viral infections: Rubella, cytomegalovirus 
(CMV), varicella-zoster virus (VZV), herpes simplex virus (HSV), parvovirus B19 and human immunodeficiency virus (HIV), Reprod Toxicol 21 (2006) 350-382.

[13] M.I. Arleevskaya, A.Z. Shafigullina, Y.V. Filina, J. Lemerle, Y. Renaudineau, Associations between Viral Infection History Symptoms, Granulocyte Reactive Oxygen Species Activity, and Active Rheumatoid Arthritis Disease in Untreated Women at Onset: Results from a Longitudinal Cohort Study of Tatarstan Women, Front. Immunol. 8 (2017) 1725.

[14] D. Aletaha, T. Neogi, A.J. Silman, J. Funovits, D.T. Felson, C.O. Bingham, 3rd, N.S. Birnbaum, G.R. Burmester, V.P. Bykerk, M.D. Cohen, B. Combe, K.H. Costenbader, M. Dougados, P. Emery, G. Ferraccioli, J.M. Hazes, K. Hobbs, T.W. Huizinga, A. Kavanaugh, J. Kay, T.K. Kvien, T. Laing, P. Mease, H.A. Menard, L.W. Moreland, R.L. Naden, T. Pincus, J.S. Smolen, E. Stanislawska-Biernat, D. Symmons, P.P. Tak, K.S. Upchurch, J. Vencovsky, F. Wolfe, G. Hawker, 2010 Rheumatoid arthritis classification criteria: an American College of Rheumatology/European League Against Rheumatism collaborative initiative, Arthritis Rheum. 62 (2010) 2569-2581.

[15] B. Bruce, J.F. Fries, The Stanford Health Assessment Questionnaire: dimensions and practical applications, Health Qual Life Outcomes 1 (2003) 20.

[16] D.T. Felson, J.J. Anderson, M. Boers, C. Bombardier, M. Chernoff, B. Fried, D. Furst, C. Goldsmith, S. Kieszak, R. Lightfoot, et al., The American College of Rheumatology preliminary core set of disease activity measures for rheumatoid arthritis clinical trials. The Committee on Outcome Measures in Rheumatoid Arthritis Clinical Trials, Arthritis Rheum. 36 (1993) 729-740.

[17] E. Inoue, H. Yamanaka, M. Hara, T. Tomatsu, N. Kamatani, Comparison of Disease Activity Score (DAS)28- erythrocyte sedimentation rate and DAS28- Creactive protein threshold values, Ann. Rheum. Dis. 66 (2007) 407-409.

[18] Arleevskaya M, Albina S, Larionova RV, Gadbdoulkhahova AG, J. Lemerle, R. Y., Prevalence and incidence of upper respiratory tract infection events are elevated prior to the development of rheumatoid arthritis in first-degree relatives, Front. Immunol. (2018).

[19] R. Barnett, G. Larson, A phenol-chloroform protocol for extracting DNA from ancient samples, Methods Mol Biol 840 (2012) 13-19.

[20] J.M. Bennett, R. Glaser, W.B. Malarkey, D.Q. Beversdorf, J. Peng, J.K. KiecoltGlaser, Inflammation and reactivation of latent herpesviruses in older adults, Brain Behav Immun 26 (2012) 739-746.

[21] N. Sherina, H.S. Hreggvidsdottir, C. Bengtsson, M. Hansson, L. Israelsson, L. Alfredsson, K. Lundberg, Low levels of antibodies against common viruses associate with anti-citrullinated protein antibody-positive rheumatoid arthritis; implications for disease aetiology, Arthritis Res. Ther. 19 (2017) 219. 
[22] A. Nazmi, A.V. Diez-Roux, N.S. Jenny, M.Y. Tsai, M. Szklo, A.E. Aiello, The influence of persistent pathogens on circulating levels of inflammatory markers: a cross-sectional analysis from the Multi-Ethnic Study of Atherosclerosis, BMC Public Health 10 (2010) 706.

[23] J. Zhu, A.A. Quyyumi, J.E. Norman, G. Csako, M.A. Waclawiw, G.M. Shearer, S.E. Epstein, Effects of total pathogen burden on coronary artery disease risk and Creactive protein levels, Am J Cardiol 85 (2000) 140-146.

[24] K. Vahdat, F. Azizi, K. Zandi, M. Assadi, I. Nabipour, Chronic inflammation is correlated with percentage of body fat independent of the burden of infection, Inflammation 35 (2012) 1322-1329.

[25] Y. Shapira, B.S. Poratkatz, B. Gilburd, O. Barzilai, M. Ram, M. Blank, S. Lindeberg, J. Frostegard, J.M. Anaya, N. Bizzaro, L.J. Jara, J. Damoiseaux, Y. Shoenfeld, N.A. Levin, Geographical differences in autoantibodies and anti-infectious agents antibodies among healthy adults, Clin. Rev. Allergy Immunol. 42 (2012) 154163.

[26] M.K. Meron, H. Amital, D. Shepshelovich, O. Barzilai, M. Ram, J.M. Anaya, R. Gerli, N. Bizzaro, Y. Shoenfeld, Infectious aspects and the etiopathogenesis of rheumatoid arthritis, Clin. Rev. Allergy Immunol. 38 (2010) 287-291.

[27] M. Cai, M. Li, K. Wang, S. Wang, Q. Lu, J. Yan, K.L. Mossman, R. Lin, C. Zheng, The herpes simplex virus 1-encoded envelope glycoprotein B activates NFkappaB through the Toll-like receptor 2 and MyD88/TRAF6-dependent signaling pathway, PLoS One 8 (2013) e54586.

[28] P. Lacerte, A. Brunet, B. Egarnes, B. Duchene, J.P. Brown, J. Gosselin, Overexpression of TLR2 and TLR9 on monocyte subsets of active rheumatoid arthritis patients contributes to enhance responsiveness to TLR agonists, Arthritis Res. Ther. 18 (2016) 10.

[29] N. Salloum, H.M. Hussein, R. Jammaz, S. Jiche, I.W. Uthman, A.M. Abdelnoor, E.A. Rahal, Epstein-Barr virus DNA modulates regulatory T-cell programming in addition to enhancing interleukin-17A production via Toll-like receptor 9, PLoS One 13 (2018) e0200546.

[30] M. Torigoe, K. Sakata, A. Ishii, S. Iwata, S. Nakayamada, Y. Tanaka, Hydroxychloroquine efficiently suppresses inflammatory responses of human classswitched memory B cells via Toll-like receptor 9 inhibition, Clin. Immunol. 195 (2018) 1-7.

[31] B.M. Veetil, E. Myasoedova, E.L. Matteson, S.E. Gabriel, A.B. Green, C.S. Crowson, Incidence and time trends of herpes zoster in rheumatoid arthritis: a population-based cohort study, Arthritis Care Res (Hoboken) 65 (2013) 854-861. 
[32] M.C. Genovese, R. Fleischmann, B. Combe, S. Hall, A. Rubbert-Roth, Y. Zhang, Y. Zhou, M.F. Mohamed, S. Meerwein, A.L. Pangan, Safety and efficacy of upadacitinib in patients with active rheumatoid arthritis refractory to biologic diseasemodifying anti-rheumatic drugs (SELECT-BEYOND): a double-blind, randomised controlled phase 3 trial, Lancet 391 (2018) 2513-2524.

[33] A.L. Gavin, D. Huang, C. Huber, A. Martensson, V. Tardif, P.D. Skog, T.R. Blane, T.C. Thinnes, K. Osborn, H.S. Chong, F. Kargaran, P. Kimm, A. Zeitjian, R.L. Sielski, M. Briggs, S.R. Schulz, A. Zarpellon, B. Cravatt, E.S. Pang, J. Teijaro, J.C. de la Torre, M. O'Keeffe, H. Hochrein, M. Damme, L. Teyton, B.R. Lawson, D. Nemazee, PLD3 and PLD4 are single-stranded acid exonucleases that regulate endosomal nucleic-acid sensing, Nat. Immunol. 19 (2018) 942-953.

[34] Y.H. Lee, S.C. Bae, G.G. Song, Meta-analysis demonstrates association between TLR polymorphisms and rheumatoid arthritis, Genet Mol Res 12 (2013) 328-334.

[35] C. Potter, H.J. Cordell, A. Barton, A.K. Daly, K.L. Hyrich, D.A. Mann, A.W. Morgan, A.G. Wilson, G. Biologics in Rheumatoid Arthritis, S. Genomics Study, J.D. Isaacs, Association between anti-tumour necrosis factor treatment response and genetic variants within the TLR and NF\{kappa\}B signalling pathways, Ann. Rheum. Dis. 69 (2010) 1315-1320.

[36] M.L.R. Davis, T.D. LeVan, F. Yu, H. Sayles, J. Sokolove, W. Robinson, K. Michaud, G.M. Thiele, T.R. Mikuls, Associations of toll-like receptor (TLR)-4 single nucleotide polymorphisms and rheumatoid arthritis disease progression: an observational cohort study, Int Immunopharmacol 24 (2015) 346-352.

[37] S. Ramiro, C. Gaujoux-Viala, J.L. Nam, J.S. Smolen, M. Buch, L. Gossec, D. van der Heijde, K. Winthrop, R. Landewe, Safety of synthetic and biological DMARDs: a systematic literature review informing the 2013 update of the EULAR recommendations for management of rheumatoid arthritis, Ann. Rheum. Dis. 73 (2014) 529-535.

[38] S. Ramiro, A. Sepriano, K. Chatzidionysiou, J.L. Nam, J.S. Smolen, D. van der Heijde, M. Dougados, R. van Vollenhoven, J.W. Bijlsma, G.R. Burmester, M. ScholteVoshaar, L. Falzon, R.B.M. Landewe, Safety of synthetic and biological DMARDs: a systematic literature review informing the 2016 update of the EULAR recommendations for management of rheumatoid arthritis, Ann. Rheum. Dis. 76 (2017) 1101-1136.

[39] M.I. Arleevskaya, S. Albina, R.V. Larionova, A.G. Gabdoulkhakova, J. Lemerle, Y. Renaudineau, Prevalence and Incidence of Upper Respiratory Tract Infection Events Are Elevated Prior to the Development of Rheumatoid Arthritis in First-Degree Relatives, Front. Immunol. 9 (2018) 2771.

[40] R.J. Stack, M. Stoffer, M. Englbrecht, E. Mosor, M. Falahee, G. Simons, J. Smolen, G. Schett, C.D. Buckley, K. Kumar, M. Hansson, A. Hueber, T. Stamm, K. Raza, Perceptions of risk and predictive testing held by the first-degree relatives of 
patients with rheumatoid arthritis in England, Austria and Germany: a qualitative study, BMJ Open 6 (2016) e010555. 
A HSV1/2 serological profile

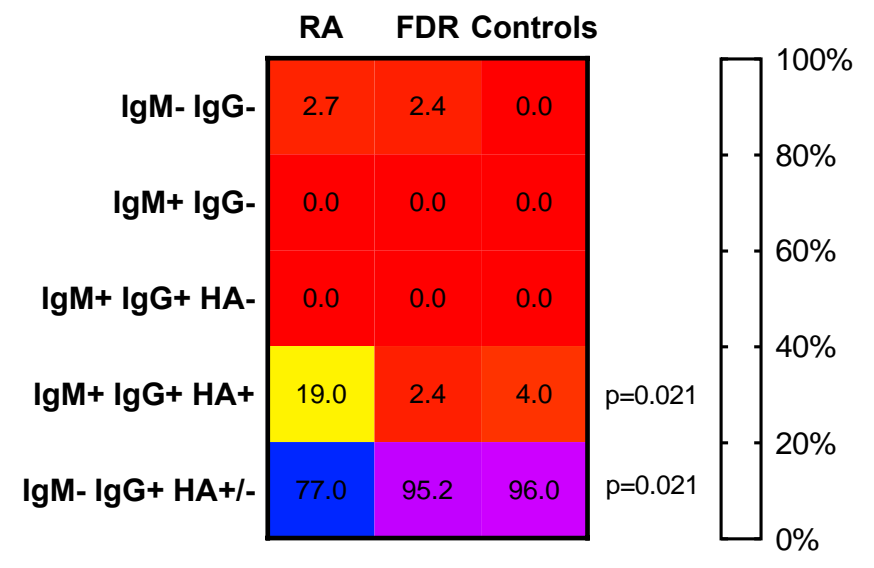

D

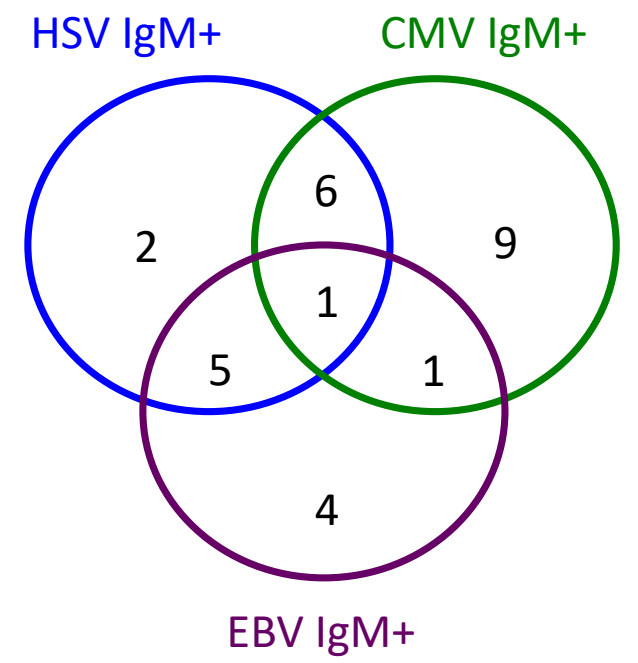

B EBV serological profile

RA FDR Controls

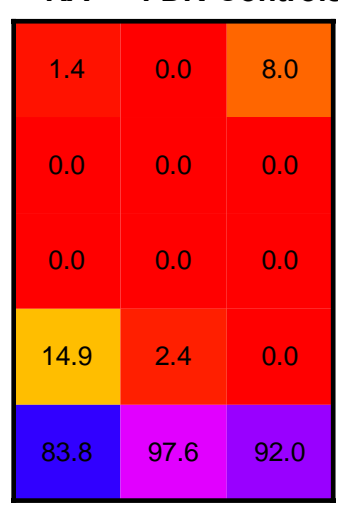

HSV1/2 PCR in RA

E

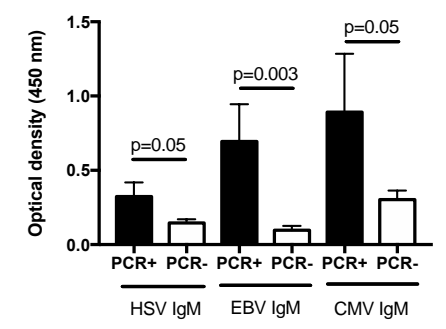

F

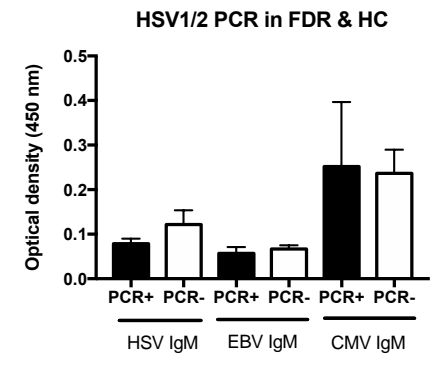

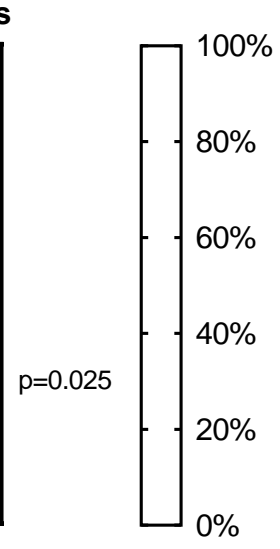

HSV symptomatic in RA

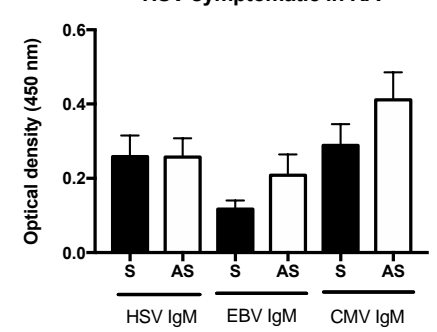

HSV symptomatic in FDR \& HC

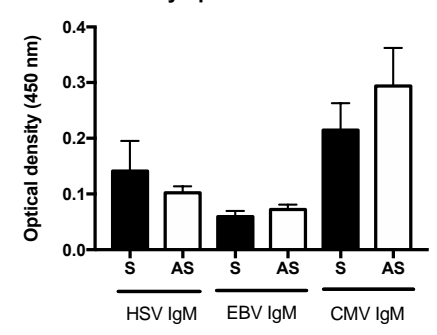

CMV serological profile

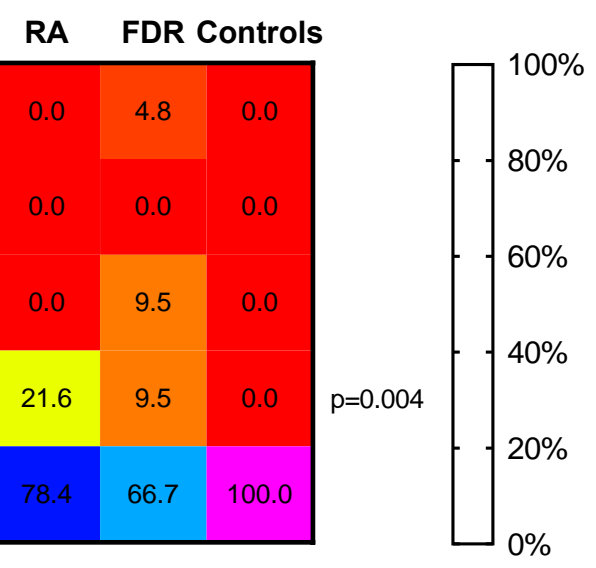

EBV PCR in RA

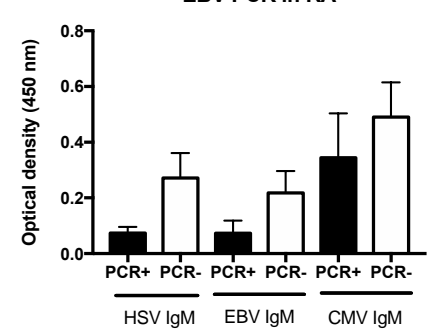

EBV PCR in FDR \& HC

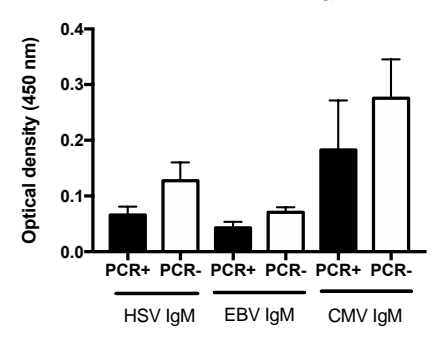

